\title{
Antonio Rosmini's Social Ethics and his Relationship to German Thought
}

\author{
Markus Krienke* \\ Faculty of Theology Lugano, CH-6904 Lugano, Switzerland
}

Received February 08 2018; Accepted February 282018

Abstract: Putting the economic and social-ethical thought of Rosmini in relationship to the German tradition of social market economy, either a pertinent collocation of the liberal catholic thinker Rosmini or new perspectives for the concept of social market economy, which is in search for a new identity, have been made. The justification of this paper lies in the fact that Rosmini introduced the idea of social justice right in the sense of social market economy, on the one hand, and in the way in which the late 19th-centrury economic theory in Italy received his economic thought, on the other hand. Hence, despite his theoretical and cultural distance from Röpke, both have many interesting economic reflections in common.

Keywords: Liberalism and catholic thought $\bullet$ Social market economy $\bullet$ Social justice $\bullet$ Rosmini $\bullet$ Röpke

"Rosmini observed astutely that due to Christianism earthly things were no longer dangerous and devastating, as it adjusted the moral ideas and brought them to perfection through its sanctions" (Minghetti 1868, p.377).

\section{Introduction: Rosmini as a pioneer of the concept of social justice}

The Italian liberal catholic thinker Antonio Rosmini is known to the social and ethical thinking in Germany so far only as a cue for the concept of "social justice." In this respect, he was on a par with Jesuit Luigi Taparelli who had used this concept a few years earlier (Küppers 2008, pp.166-167; Veith 2004, p.319). But due to missing translations the different meaning of this term is not perceived. And it is completely unknown that it has a significant precursor: Romagnosi (1791) in his Genesis of criminal law distinguished its political dimension from its traditional definitions based on virtue ethics (Mbida 2017): "it is nonsense to separate politics from social justice. This can only be the work of foolish ignorance or a misguided depravity" (Romagnosi 1791, p.941). Both authors received Romagnosi in extenso and critically, while declining especially the politicization of his concept of justice and insisted on a natural or rational foundation. Despite more than 4 decades of the German translation of the most famous Rosminian work The Five Wounds of the Church and nearly 2 decades of the German version of his Philosophy of Politics, which both included significant social and ethical reflections, this term is so far almost the only one by which Rosmini acted in the "German world." 1 Therefore, first of all, a

1 Only little attention has been given to the concept of "Antiperfektivism" or of the person as the "subsistent human right." But both can be considered concretisations of the Rosminian meaning of "social justice." 
more detailed clarification of its different meanings in all the three Italian thinkers is given to answer the methodological question in which the sense of the social-ethical thought of Rosmini can be conveyed to the "German thought."

Rosmini criticized Romagnosi for reducing the social order to facts. Instead, he preferred beginning the reflection by recognizing a priori and ideal social conditions. This is the fundamental meaning of his understanding of natural law. ${ }^{2}$ For Romagnosi, the rights are the consequence of the natural order between things and people, as they emerge historically in the society. Natural law is therefore, according to Romagnosi, extensive and diverse as the necessary conditions of the development of the people (Romagnosi 1936, pp.249-250). Thus, it is not a priori for the design of social relationships, but it is the ideal expression of the society through its historical development. However, as Tarantino correctly pointed out, in this way, Romagnosi removed the element of will from the concept of rights taken as design pattern of the social context. In the consequence, rights are the just determination between all social actors and public phenomena (Tarantino 1983, p.146, 154). For Rosmini, however, the "relationships" between things and persons are not natural, but moral and therefore imply individual freedom. Thus, the social relationship is for him a means to achieve the person - and Romagnosi's idea of the supremacy of social relationship appears as the dissolution of individuality and freedom of the person into the "facts" of social reality. For Rosmini, the social reality does not arise as a fact, but rather it is generated from relationships of recognition. In this way, he turned explicitly against Romagnosi's idea of the society, interpreting it in direct relationship to Montesquieu. ${ }^{3}$ For Rosmini, the social context therefore has a normative dimension, which results solely from the free and voluntary recognition by the individuals. Rosmini underlined that "the need, which arises from the circumstances or the aims of things, is the obligation itself

2 "Romagnosi is referring to the epistemological as well as ethical and juridical meaning of this term to a real fact as it is recognized by human being. To the contrary, the Rosminian concept means the internal order of an existing and possible, ideal, moral, real and material reality" (Tarantino 1983, p.103). "Romagnosi's utilitarianism [...] certainly is taken by Rosmini to be the counter-model of his own intellectual project" (Hoevel 2013, p.24).

3 "To others this idea of order seemed still too vague; and in trying to determine it closer, they specified its origin; and they believed to answer adequately this question in saying that the order results from the relations between things. Then they deduced that the principle of morality and legislation lays in the relations of things. Clarke in England, Montesquieu in France and Romagnosi in Italy founded this principle" (Rosmini 1990, p.383). or the moral law" (Rosmini 1990, p.390). For this reason, Rosmini did not dissipate the rights in the rational nature of man - as it was the program of the 18th century's natural law approaches. Instead, he insisted on the justification of every right only against the assumed backdrop of duty. ${ }^{4}$ For Rosmini, unlike Romagnosi, the natural order of social justice is the result of the moral reality of individual free will, while for Romagnosi any social freedom can only be conceived within the social order. For Rosmini, it is part of the nature of person, and for Romagnosi it is an element of the society. For this reason, for Rosmini, the "constitution of social justice" correlates with the "natural constitution of the society" - according to two titles of his most important philosophical and political writings (Rosmini 2010, 1887). In these writings, he introduced in an innovative way a political institution for the guarantee of the universal recognition of every person's freedom and dignity: the so-called "political tribunal" (tribunale politico). It guarantees fundamental rights and liberties, and therefore the recognition of every person, without the consequence of a substantive equality of goods, which for Rosmini could not solve the society's problems, but rather would make impossible the flourishing of person (Rosmini 1978, p.99). According to Rosmini, the person is distinguished by natural, "pre-social" rights, which the society and the legislator cannot infringe.

The possibility to recognize the moral order preceding the society is a common idea of Rosmini and Taparelli d'Azeglio. With Taparelli d'Azeglio, Rosmini shared the Thomistic reference point for his social-ethical reflections. However, Taparelli did not focus on the moral dimension of the individual in his freedom, but on the bene commune which was metaphysically determined. Therefore, individuality must constitutively be subordinated to this higher moral ideal. In this way, however, the rights are completely deprived of their political configurability, since they are now a priori determined by a metaphysical concept of nature. Taparelli refused the modern idea that the individual rights aim at the moral common good. To the contrary, for him they derive from it insofar they are anchored in it. Therefore, it would be inappropriate, at least in a social-ethical sense, to recognize a real concept of individuality for Taparelli: thus, he was not a liberal thinker at least in a strict sense. ${ }^{5}$ This result was confirmed by the repeated emphasis of Taparelli who affirmed that outside of the social context only atomistic individuals would remain without any ability to establish an autonomous social context (Taparelli 1860, p.34), but

\footnotetext{
4 "The rights follow [...] of the moral duty which imposes us not to harm any person" (Tarantino 1983, p.240).

5 The argument of Küppers (2010, p.89) is essentially different.
} 
this would precisely be Rosmini's position. For Hegel, also for Taparelli, the welfare of the superior level remains a priority and legitimizes the welfare of the inferior ones (Hegel 2008, pp. 287-289). Taparelli himself summed up his approach "in a nutshell" as follows: "The existence of natural associations of people that are equal to each other in their nature, but differ in their individuality, who have a free will, but presuppose a natural, or at least artificial principle of their unity: these are the essential facts to which we have applied the general principle of duty. As a result, a person must be governed in fact; and who governs, is the stronger and has authority. This is so. Who is subordinated does not rule. Again, this is so. And the monarchy is not a republic, nor the republic is a monarchy. Again, this is so" (Taparelli 1928, p.592). In this way Taparelli denies any existence of the person outside of the corporatist union. Only the corporatist union guarantees the common good in a social-metaphysical way. "The necessity and the rights culminate in the moral duty to socialisation; the duty to social union with the others is focused on the completion of the human common good" (Behr 2003, p.106). Therefore, for Taparelli, social justice is found on a fact, which means that it indicates not only the society that originally consists of free individuals but also the prior common good. "How can there be mutual obligations without mutual relations? How can there be conditions without any connection or a connection without any law? How can there be a law without a lawgiver and without authority? Since the connection of many rational beings under a common authority is a fact, what is lacking to establish a society?" (Taparelli 1928, p.299).

This brief overview makes clear that among these three "inventors" of the concept of "social justice" only Rosmini did not found this idea on a fact - be it society, be it natural relations of subordination - but on the moral freedom of person.

For this reason, only the Rosminian idea of social justice has produced a concept of civil society that is compatible with the requirements of modern liberalism. He succeeded to transfer the moral authority of "duty" from its anchoring in the natural law to the concept of person and therefore to the idea of freedom itself, without thereby resolving it in the social sphere. Therefore, we could hold that Rosmini is the first, who distinguished in the context of Italian thought consistently between "freedom" and "arbitrariness" in the determination of will. Hence, he introduced the concept of person with a complexity that corresponded to the demands of a modern concept of civil society, which linked individual rights and the common good in a new and productive thought. ${ }^{6}$

6 Kobusch pointed out that the fundamental distinction between arbitrariness - based on individual interests - and freedom - the
But for that matter, he reversed the Hegelian logic of civil society, because for him the universal does not predominate over the individual, this is the state over the individual, but, on the contrary, every social relationship is measured at the idea of pre-social moral recognition of the person (Krienke 2015). In this aspect, Rosmini emphasized and turned the tradition of the natural social order against Hegel. ${ }^{7}$ Therefore, Cantillo noticed entirely correct, "that even and especially by the considerations [...] on the economics of Rosmini, it has been established his liberalism and his unusual collocation in the political thinking of the restoration within the tradition of Catholic social teaching as well as in the religious communities" (Cantillo 2013, p.43). Through this concept of the society, which is at the same time complex and appropriate to the differentiation of modern social systems, Rosmini put his economic theory and his ethical reflections on it in the service of the society, that is, at the service of people. Therefore, for Rosmini, the social theory stands at the center of his political thought, to which the understanding of the state is aligned, not vice versa.

\section{The perception of Rosmini in the German social-ethical discourse}

The explanation of the Rosminian concept of "social justice" makes it clear because the German-speaking social-ethical reflection not only has been putting for quite some time at least encyclopedic interest to it but also can intensify and deepen this previously attempted curiosity. But which is the exact status of the perception of Rosmini in the German social-ethical thinking? It is important to refer particularly to the 1999 published translation of the Philosophy of politics by Liermann (Rosmini 1999), who not only prefaced an introduction but also published 5 years later an elaborated monograph on Rosmini's political thought. Therein, she interpreted the Rosminian concept of civil society, describing it as the attempt "to pick up the impulses of the economic logic of capitalism and the bourgeois work ethics, merging them

willing and affirmation of other freedom - goes back to Hegel who thus introduced a new level of reflection on social freedom (Kobusch 1997, p.161). This distinction then returns in the difference between "first-order desires" and "second-order desires" in the study by Frankfurt and Taylor. Further, it is of fundamental importance for the understanding of Ordoliberalism, as it will become clear in the following sections.

7 The valid aspect in Hegel's thought, which characterizes also Rosmini's thought, can be identified together with Siep in the following way: “Certain duties for a subject which is 'morally' self-determining are possible only in relation to a particular way of personal community, which secures the freedom of individuals, by assuring their own freedom against their casual and accidental purposes" (Siep 1982, p.94). 
with traditional Catholic maxims of justice" (Liermann 2004, p.447). ${ }^{8}$ Rosmini's social-ethical concerns are therefore perfectly read as an integration of the modern free market economy with the Christian anthropology. On the one hand, the free market economy is recognized in its social dimension and collocated in its socialethical context, whereby any sort of liberalism that cancels the moral dimension of the individual is rejected, and on the other hand, the Christian anthropology is accepted as normative criterion for any social order, avoiding and excluding all forms of socialist and collectivist concepts a priori.

The indispensable prerequisite for such a liberal conception in a Christian view is, for Rosmini, the "antiperfectionism": the task of social-ethical systems is not only to overcome directly social illnesses but also to guarantee the personal ethical freedom for all members of the society against social despotism - that is, structures of power and monopoly - and to create in this way the best conditions for the elimination of evil in civil society. For this reason, the up-to-date study by Piovani (1957), which was published in a German translation in 2013, is of great relevance: Abhandlungen zur gesellschaftlichen Theodizee bei Antonio Rosmini-Serbati. The translator attested to the social-ethical thought of Rosmini, to be "relentlessly up-to-date," despite his difficult language (Hebeisen 2013, p.6). Rosmini appeared, in the paper, as a pioneer of free market economy, proactivity, and as a promoter of a liberal social order. Any social order can be legitimized only when its function is not only to alleviate all social illnesses but also to create the adequate institutional conditions for developing the whole potential of human freedom.

Another Rosminian work that evokes the social-ethical interest is The Five Wounds of the Church (Rosmini 1971), which deals among other things about the importance of the Church's reform for a modern understanding of the society. Traniello pointed out in a paper published in German that Rosmini analyzed in his work the problem that "the Christian penetration of the secular society

8 In addition, she specified that "Like the liberal economy Rosmini was convinced that an inequality which is justified in this way - being at the same time not fixed in its scope, but dynamic - is an essential condition of social prosperity: as an incentive that releases ambitioned forces and stimulates performance. On the other hand, such a modern capitalist justification of inequality was in his eyes not without any problems, because part of that logic was legitimizing a negative phenomenon for its expectable positive consequences. To Rosmini it seemed ethically indefensible, to endorse morally reprehensible attitudes, such as envy, greed, selfishness, which could be the result of inequality, arguing that they induce people to increase work effort and aspiration. This dilemma, which he regarded as one of the great inner conflicts of modern societies, seemed to Rosmini ultimately not to be resolvable" (Liermann 2004, pp.447-448).
[...] dialectically turned into a profound secularization of Church" (Traniello 2007, p.409; Traniello 1999).

Some other studies, such as Nicoletti's paper on the "political tribunal" in Rosmini's thought (Nicoletti 1999) or Campanini's work on the concept of civil society (Campanini 1999), flank these three major expressions of the interest for the social and ethical thought of Rosmini in the German sphere. Thus, it is clear that the attention relates to the constitutional and liberal fundament of his political thought, while the importance of Rosmini's economic thinking in relationship to the social-ethical overall context of his thought has not yet been sufficiently considered. In fact, Rosmini never dedicated an own systematic treatise to the economic system, but it is also clear that his economic and ethical considerations accompany always his social-ethical instances. Only if considering this aspect, one can become aware of Rosmini's socialethical approach in its entire width. Conversely, in the Italian- and English-speaking sphere, there are some studies on the economic thought of Rosmini, which characterize him sometimes as anti-liberal, sometimes as a classical liberal thinker, and some people find in him even significant parallels to the thought of Hayek. Yet, others evidence its roots in the thinking of Antonio Genovesi or Gaetano Filangieri (Genovesi 1824, p.243; Filangieri 2003, p.12) with its central concept of "civil economy," like the recently published English-language study by Hoevel (2013, pp.22-23). In this debate, however, it is commonly overlooked that the German-language perspective on Rosmini can make a significant contribution to the understanding of his social-ethical thought, namely by trying to bring him together with the economic approach of social market economy. Before satisfying this desideratum, there is the question why this relationship has yet not been seen or why Rosmini's thought has not yet gained attention by the "German thought" of social market economy.

\section{The history of the effects of Rosmini's thought}

Before speaking about a still non-existing relationship, it should briefly be considered the Wirkungsgeschichte of Rosmini's economic thought in the second half of the 20th century, mainly because Rosmini was linked to the "German world" by some influential Italian economists. Furthermore, a more detailed and closer look on these thinkers as well as on Rosmini himself frees them from a flat classification as "socialists of the chair" (historical school of economics). This account sketches those thinkers who are proven to have been greatly influenced by Rosmini: Minghetti, Toniolo, Lampertico, and Luigi Sturzo (Pisu 1988, p.294). 
Regarding the first thinker, who was after all in 1861 Minister of the Interior and from 1863 to 1864 and from 1873 to 1876 President of the Italian Council of Ministers (the government), there had not yet been any reference to the influence that Rosmini had on his theory of property (Ghia and Marangon 2015, p.196). In his work, Della economia pubblica, Minghetti wrote that in the foundation of property "the German school started with the human person and the connection between it and the appropriated things: this theory was then presented by Rosmini and completed" (Minghetti 1868, p.402). With "German school," Minghetti indicated, on the one hand, the approaches, which actually succeeded Rosmini, by namely Roscher, Knies, and Schmoller, and, on the other hand, probably the idealistic thought at the beginning of the century. Both times, the "completion" of their teachings consisted in the recognition of the anthropological dynamics in the acquisition of property, which according to Rosmini constituted a threefold, "intellectual," "physical," and "moral" bundle (Minghetti 1868, p.404). ${ }^{9}$ In the paper, Minghetti raised really the central issue of Rosmini's social-ethical thought: the person as the center of all economic, political, and social institutions. As Minghetti pointed out, for Rosmini, economic freedom consists in the liberty of the person, who is, according to him, "subsistent human right" (Rosmini 1993, p.21), and therefore she expresses herself in the idea of right. In this way, Minghetti revealed the Rosminian mark of his thought and testifies that "the specific economic freedom is nothing more than a consequence of the general juridical freedom; and the free choice of the means which everyone considers most appropriate to obtain satisfaction is part of the full possession and use of the own abilities" (Minghetti 1868, p.394)..$^{10}$ The influence of Rosmini to Minghetti, whose writings give on every page an expression of the Rosminian formation of his thought, is then highlighted by Toniolo (1952, p.370). Toniolo described Rosmini as one of "our most famous philosophers and writers on the social issues in general" (Toniolo 1949-1952, II, p.287), who emphasized the value of "freedom, sociability, and authority" as principles of civilization and trade (Toniolo 1949-1952, $\mathrm{V}, \mathrm{p} .229)$. By "defending positive faith against the rationalism of the revolution," Rosmini presented an image of the society, in which "society remains essentially

9 In addition, Zoppi highlighted this aspect in his analysis, to which we will return (Zoppi 1897, p.436).

10 According to Rosmini, the "liberalism, which we mean, is a system of law and also the policy that guarantees to all the precious treasure of their juridical freedoms" (Rosmini 1978, pp.87). However, as Graziani criticized, Minghetti's knowledge of Rosmini did not go beyond the doctrine of property, because he did not refer to other Rosminian fonts and themes (Graziani 1887, p.453). spiritual, and yet economic prosperity, the son of meritorious work, was necessary and noble, because it leads to it" (Toniolo 1949-1952, I, p.153, 305).

Lampertico referred to Rosmini directly in two writings pointing out that "Rosmini had wide beneficial effects on the thinking in Italy, no less than Aristotle or Kant."11 Lampertico highlighted how the political and economic implications to acting result from the ethical impact of Rosmini's anthropology (Lampertico 1897b, p.20).

Finally, Luigi Sturzo must be mentioned as an important thinker who has taken the consequences of Rosmini's ideas for the development of the ethics of rights and business ethics. He was interested not so much in Rosmini's theoretical works about the philosophy of rights and politics, which seemed to him still bound to the social conditions of the early 19th century. Instead, he connected directly with his theory of knowledge, ethics, and anthropology to develop the political and economic consequences from his concept of person (D'Addio 2001, p.72, 74). For the development of neo-Thomism, Sturzo was totally unsuited to afford a confrontation with modernity. D'Addio highlights how the Rosminian ideas influenced Sturzo and the program of the Partito Popolare Italiano and cites contemporaries who recognized "a continuity of its spiritual, civil and political inspiration with the most important Italian representatives of the Catholic-inspired liberalism of 19th century" (D'Addio 2001, p.80, 83). He took directly Rosmini's concern that the welfare state could absorb the rule of law and the freedom entirely in itself. "The moral conscience, the sense of responsibility, the awareness of the limits: these are for Sturzo the essentials of Rosminian spirit and the constitutive principles of the 'spirit' of the democratic and representative constitution. They 'practice' continuous control over the policy in order to preserve it and, if necessary, to bring it back to the scope of the standards and the objectives of the Constitution" (D'Addio 2001, p.102; Sturzo 1972).

To understand the direct Wirkungsgeschichte of Rosmini in the economic and social-ethical thinking of the 19th century, it is important to consider a paper, which appeared in the two famous jubilee volumes on occasion of the 100th birthday of Rosmini in 1897. In that paper, Antonio Rosmini e l'Economia politica, Zoppi set out how Rosmini's fight against the consideration of economic and social institutions with the sole instrument

11 Unlike Ghia and Marangon claimed, the discourse Antonio Rosmini o la sapienza e la scienza nella vita was not published in the two volumes on the occasion of the 100th birthday of Rosmini (Ghia and Marangon 2015, p.196), but was separately published (Lampertico 1897b, p.4). Moreover Lampertico referred to Rosmini a second time (Lampertico 1897a). 
of empiricism and sensationalism was the determining influence of Rosmini on the Italian thought in the second half of the 19th century. Its representatives, indeed, explicitly opposed the "civil-economic" approaches of the humanism of Genovesi, Filangieri, Pagano, Galiani, etc. and showed a still insufficient removal of the empiricistsensualist doctrines. Calza and Perez, who presented an influential three-volume interpretation of Rosmini's thinking, described that "an even cursory reading of their writings in the light of many wonderful ideas and highly respectable intentions finds soon not few prejudices that have been taken over by the contemporary French thinkers. They consist primarily in infinite inaccuracies that always emerge when it comes to the duty, which is never separated from the well-being, the interest or other instincts, which are all only subjective, much as they are refined by the names of humanity and universality" (Calza and Perez 1878-1879, I, pp.38). Significantly, the commentary on the Rosminian texts by the thought of Fedele Lampertico is the main characteristic of this study. Zoppi highlighted how the Rosminian doctrine of the "harmonious unity of human nature" was received especially against the economic doctrines that consider the propensity to consume as actual economic development factor. For Rosmini, this doctrine was already found in Melchiorre Gioia (Gioia 1838-1839; Rosmini 1994b, p.317). However, for Rosmini as well as for his commentators, economy is only moral when it is focused on the "satisfaction" (appagamento) of people, not on the mere maximisation of "consumption" (Zoppi 1897, p.413). The free market economiy does not become problematic because individuals can seek for personal profit, but when it becomes oriented immorally or when some economists teach that pure consumerism is the basic economic factor. "The tendency to the whims of fashion and luxury is essentially immoral. It is the result of vanity and human stupidity. Therefore, they must not be preached and inculcated, even if that brings some advantages" (Zoppi 1897, p.417, 421). For this reason, consumption is not to be condemned as such and in general. Instead, Rosmini would restore the teaching of the "economists of the old Anglo-German school." Zoppi referred here to the classical liberal idea that nonmaterial values can only be considered as "richness" when they stand in relationship to material values and can be counterweighted against them (Zoppi 1897, p.423). Such a resumption of the classical liberal idea is, according to the "Rosminian" Zoppi, not a step backward but a real progress in economic reflection. In addition to his doctrine on "wealth," Rosmini exercised, so Zoppi, another great impact on the socio-ethical and economic thinking of the late 19th century: his consistent anti-socialism and anti-communism.

Rosmini had clearly studied the beginnings of these doctrines in England and France and also saw the teachings of Karl Marx. In his view, socialism was the consequence of abstracting the economic thinking completely from any "ethical and juridical relationship," so that it "can be converted by socialism without any respect for rights and morality" (Zoppi 1897, p.427). Thus, the errors of socialism are not primarily economic, but above all ethical and juridical. Rosmini would not reject the social nature of man, and not even the idea that he was part of a "social organism" (Zoppi 1897, p.430), but the negation of a presocial nature of man and of human freedom, which therefore are situated before and outside any political state. This reflection brought Zoppi then directly to an in-depth analysis of the concept of property in Rosmini. In conclusion, Zoppi put the probably most crucial question for our essay, how Rosmini would relate to the "historical school of economics," which was not condemned by Christian thought and to the contrary was expressly affirmed by some "Christian socialists" (Zoppi 1897, p.443). He answered first that Rosmini would have completely rejected this expression of "Christian socialism" as a "hybrid connection" and as the "cause as well as result of a great confusion in the concepts" (Zoppi 1897, p.444). ${ }^{12}$ But then, however, in the matter how to find a "middle ground" between liberalism and socialism, which would be nothing other than "Caritas applied on the conditions of our time" (Calzi, quoted in Zoppi 1897, p.445), Rosmini would have made "concessions" to the "so-called Christian socialism" (Zoppi 1897, p.446). Then, Zoppi enumerated almost exactly those elements that Rosmini de facto had in common with the concept of "social market economy," but without mentioning Walter Eucken (Eucken 1992).

A final perspective at the end of the 19th century which connected Rosmini with the German thought is the already indicated study by Graziani: "One should observe the sharpness with which Rosmini classifies in this regard the first-degree goods of direct or indirect suitability from the second-degree ones with indirect suitability and so on. This division is very similar to that which has been done in our days by Menger. He distinguishes the goods in those of first, second, third, fourth, etc. order, depending on whether they have direct or more or less indirect suitability to meet the needs. This division was further taken over by the studies of Wieser, Gross, Mataia, Böhm-Bawerk and Sax and so it has become the occasion of a remarkable scientific progress. Therefore, I think that this division is a great merit of Rosmini, while it does not lessen Menger's merit, who formulated his doctrine regardless of Rosmini with great wisdom. He increased it with other principles and applied it on the solving the fundamental problems of value and distribution of wealth" (Graziani 1887, p.458).

12 In addition, Piovani (2013 II, p.603) agreed with this conclusion. 
From this brief overview of the historical impact of the economic and ethical thought of Rosmini in the second half of the 19th century, one can conclude that, from a today's perspective, a comparison with the concept of "social market economy" and especially with the thinking of Röpke appears more than legitimate. For this, the Wirkungsgeschichte set centrally two dimensions out: on the one hand, the concept of property and person of Rosmini, who set him apart from the Neapolitan "civil economy," and, on the other hand, his more than resolute anti-socialism, which separated him from the "socialists of the chair" approaches. This specific combination of both elements - together with other elements of theory - characterizes exactly the thinking of Röpke, although they - Rosmini and Röpke - lived and thought in very different cultural and intellectual worlds.

\section{Rosmini: precursor of the social- ethical model of the social market economy}

It is certainly not a coincidence that many issues, which emerged considering the historical impact of Rosmini on the economic thought of the second half of the 19th century, are also highlighted in the center of the ordo-liberal tradition and the "social market economy." In the same way as the representatives of these thoughts, Rosmini looked for a "new liberalism" and a "third way," which was aligned against "an undoubted innocent economic naturalism of the physiocratic political economy, and against an undoubted innocent crematism of the liberalistic school of free trade" (Piovani 2013, p.229 ${ }^{13}$ ). At the same time, he rejected any shaping of the society caused by a planned economy pretends to realize in the name of freedom and dignity of the individual. To the contrary, for Rosmini, person is to be realized positively in the economic and civic order.

The fundamental conformity with the social market economy approach lies without any doubt in the idea of person who is determined by nature, not by social relationship (Muscolino 2010, p.22, 107-108). The natural and a priori order, which anchor the person in his/her moral freedom, is for Rosmini as well as Röpke the basis of any social order and the norm of social justice. For both of them, "nature" is not simply, as for Romagnosi, "social nature," but not even, as it is for Taparelli, a metaphysical determination of the common good. It is understood, in contrast, in a personalistic sense as aligned toward the realization of personal dignity as a moral freedom.

13 At this point, as well as in many others, the German translation of Piovani's work is not reliable (Piovani 1957, p.107).
As it has already become clear, Rosmini's normative idea of the society is that of the equality of freedom, on the one hand, and that of the free competition which allows material inequality, on the other hand. For that reason he tried to mediate the two constitutional principles of "justice" and "benefits" to each other. To achieve this synthesis, he embedded the right on private property as the principle of the society in a fundamental idea of moral freedom, which is nothing else than the realization of the personal human dignity. The social framework that realizes this embedding is therefore a positive guarantee for the realization of this dignity - it thus has the social and ethical function of realizing justice and is not only a non-intentional result of intentional acts: "Respect to the instinctive inclinations, the constitution of the civil society must therefore be oriented and disposed in a way to help the human beings in the satisfaction of human inclinations, through the promotion of external goods and the limitation of all evil, and to prevent possibly all opportunities for people to abuse these to their own mischief and misfortune" (Rosmini 1887, p.4). The function of the state thus is to guarantee freedom, although it may not become an economic actor: "The government of civil society must not be turned into a business or industrial enterprise: This would be diametrically opposed to the goal of this institution, which is to protect the freedom and the profit seeking competition of the citizens, without interfering with them or compete with them" (Rosmini 2010 , p.130). And again, Rosmini underlined in an ordoliberal way that the government must defend the challenges of freedom, remove the obstacles, and "help each individual" (Rosmini 1994b, p.94). At a significant point in his Philosophy of Right, Rosmini defined four functions of the state, which correspond to his idea of a free society and enable social justice, explicating the task of this impartial and strong state, which Rosmini denoted as the regulation of modality of rights": "1. to defend one's rights; 2. settle disputes; 3. modify the exercise of the rights of individuals either to prevent the harm threatened without such modification, or 4 . to obtain a benefit which would be impossible if everyone exercised their rights without regard for the rights of others" (Rosmini 1993, p.238 [II, 2130]). All the four tasks corresponded to a systematic theory element in the study by Röpke (1944, 1950, 1961, 2006).

In general, the "regulation of modality of rights" means that the task of governmental regulatory sovereignty is to set the suitable rules of the society to avoid any restriction of freedom and rights (first task), "so that in exercising them no one may harm another, and each may help all" (Rosmini 1993, p.15 [II, 1587]). Thus, the formation of power and monopoly situations must be prevented. In fact, once, Rosmini expressly treated 
the problem of monopolies and estimated that the modern "hatred of every kind of monopoly clearly indicates the progress of civilisation and the prevalence in modern societies of the civil element over the seigniorial element" (Rosmini 1993, p.292 [II, 2294]). It is the meaning of the following principle, "to remove everything that impedes free concurrence" (Rosmini 1993, p.242 [II, 2142]). ${ }^{14}$ As obstacles to free concurrence, he enumerated the following concretizations: "privileges, customs, prejudices, etc." This principle of the society corresponds the limitation of the government activity to the "policy framework" and the ordo-liberal doctrine of "market-oriented" acting of the state (Röpke 1944, p.76). The state has to defend the rights of all, and Rosmini entrusted this duty to the institution of the "political tribunal." In his Philosophy of Politics, Rosmini stressed that "[b]ecause of its impartiality, government does not concern itself with individuals as such" (Rosmini 1994b, p.303). Rosmini underlined here the "strong and independent" role (Röpke 1944, p.33) ${ }^{15}$ of an arbitrator who stands above all parties and monitors compliance with the standards on the part of all social actors. This characteristic was lamented by Rosmini especially when he claimed that civil society "must be strong; it must have at its disposition a force sufficient to repress the perverse, and banish fear in the good" (Rosmini 1993, p.240 [II, 2135]).

The second government function, summarily called the settlement of disputes, is for Rosmini the primary responsibility of the family, which can be replaced by the arbitrator's responsibility of the society only when the dispute cannot be resolved at the level of families: "civil society must not intervene officially in family disputes" (Rosmini 1993, p.242 [II, 2141]). In these words, a Rosminian formulation of the principle of subsidiarity can clearly be detected (Röpke 1944, p.179).

The third government task for Rosmini is to eliminate privileges, guarantee all the exercise of freedom as far as possible, and determine the rights so that their essence remains unchanged. This dimension can be explained with Röpke's doctrine of "liberal interventionism" more precisely with its second formulation referring to the "conform [...] interventions" (Röpke 1944, p.78).

14 Here, it becomes clear that Rosmini used the term "concurrence" in a wide way, i.e., not only in its economic dimension but also as indicating the means of realization of the individual-personal principle in all its social dimensions, that is "for all goods that can be objects of right" (Rosmini 1993, p.242 [II, 2142]).

15 Without such a state, according to Rosmini and Röpke, "a genuine and real market economy cannot exist” (Röpke 1950, p.192).
The fourth point concerns the positive tasks of the government, especially the use of the commons to guarantee the realization of the state functions, on the one hand, and of the few state functions that really relate to the common good, on the other. It also includes the "stimulation of moral-intellective-industrial progress by means of rewards for free concurrence" (Rosmini 1993, p.244 [II, 2147]). This can be considered the first formation of the "liberal interventionism": according to its principle of "adaptive interventionism," it is a public duty "to mitigate the hardships and frictions of changes and disturbances in economic life and to help vulnerable groups in their struggle for existence, in order to do justice in equal measure to the sense of the market economy as well as to the simple dictates of reason and humanity meet" (Röpke 1944, p.77). In the paper, we can find clear expression of the "social" component of the market economy of Rosmini.

These principles of the ordo serve for Rosmini as well as Röpke to establish the principle of competition as a positive principle of the society, for which it is important to look at it not as a goal but as a means: "By jural concurrence I mean concurrence by right, concurrence protected by rational Right. Note carefully, I never speak about a truly unlimited concurrence; the only concurrence I support is that limited by rational Right alone" (Rosmini 1993, p.293). Hereby, Rosmini considered that the government "must first ensure that the smallest part of attainable good is not wasted, even if the good has to be accumulated in certain individuals to obtain this aim" (Rosmini 1994b, p.301). In this way, he expressed that equality must find its measure and goal in freedom, not vice versa, and government "truly acknowledges in everyone an equal right to compete for the good. Certainly, the government does not admit an equal right ad rem, provided the circumstances are always the same" (Rosmini 1994b, p.301). For Rosmini, the market is thus an important institution to "save [...] civil society from all the injustices" (Rosmini 1993, p.284). Clearly, he noted: "I fully support free competition for every kind of good, provided we do not misunderstand 'competition', an undetermined and equivocal word." This precisely happens when it is regarded "as the sole source and principle of justice," i.e., as category of moral purpose. On the contrary, competition should only be the "effect, not the cause of justice," because justice "is anterior to and therefore determines the right of competition" (Rosmini 1994b, p.337).

On this basis, Rosmini presented an interpretation of the dynamics of social development: the logic of freedom that results out of individual decisions, as it promotes the system of free market economy in an ordo according to social justice, is based on socio-cultural 
conditions that Rosmini elaborated in a culturalhistorical perspective (incivilmento) (Romagnosi 1936, pp.345-460). For Rosmini, a stable society is characterized by the balance between the "practical reason of the masses" and the "speculative reason of the individuals" (Rosmini 1994a, p.50). This relationship is the criterion to fathom the moral status of different political cultures. Focusing initially only on the "practical reason of the masses," Rosmini distinguished an era of "infancy of a society." This is the moment of its "foundation," in which "the very existence of the society itself is the good seen immediately and vividly by all." Rosmini described it as "patriotic epoch" (Rosmini 1994a, p.52). In the subsequent epoch, in which the existence of the society is secured and provided, the goods are directly aimed "to the development of the society itself, and its power and glory." From this period, it goes into "the period of luxury and enjoyment," which is awarded by the "love of tranquil, peaceful pleasures" (Rosmini 1994a, p.52). Nevertheless, it is a time of decline, leading to an increasingly powerful highlights of selfishness, and in which the nation "has entirely lost sight of the rule" that governs the development of the people, until "the ultimate, single thought of the people is directed to "bread and circuses'" (Rosmini 1994a, pp.52-53). In every epoch, however, there is also a "speculative reason of the individuals" that is working, which best unfolds in the two middle periods. According to Rosmini, "it is the second social stage which prompts the movement of the greatest quantity of intelligence in nations, and gibes the masses the greatest proximate power for applying their own understanding" (Rosmini 1994b, p.164). The reason lies in the fact that the "desire for power and glory, nourished by prosperity [...] has a wonderful capacity for sharpening minds" and thus leads to a subordination of the "family society" under the civil society and to the establishing of a "perpetual fount of intelligence" (Rosmini 1994b, pp.164-165). In addition, the third era, that of wealth, has an advanced use of the intelligence that is realized now by trade, crafts, and agriculture (Rosmini 1994b, p.167). In his work, Rosmini spoke about the modern trade, i.e., the universal form of the economy, which promotes the most the abstractive capacities of intelligence. The risk, however, is that the masses "begin insensibly to weaken and use up the power acquired over their intelligence" (Rosmini 1994b, p.167). Especially between the second and the third stage, it is clear that "civil society is the political expression of increased intelligence, of a realized morality and of a new way to live the freedom" (Baggio 2016, p.133). The market has always to be considered in the interior of this civil society. In addition, when it breaks away from this context, it leads directly to the breakdown of the society and thus to its dissolution. Whithin this evolution, Christianity contributes essentially to the good use of intelligence and thus to the wealth and progress of the society by helping to avoid that the "logic of the masses" wins supremacy over it (Baggio 2016, pp.422-432).

Rosmini's analysis of the evolutionary dynamics of society through history up to the beginning of the 19th century, finds in Röpke's work its further course ahead. In fact, he spoke about the "massification" of the society, in which "the individuals become more and more absorbed in the amorphous mass." He specified that "we want to say that society, as far as this process has progressed, has lost its horizontal and vertical fine-grained structure and is gripped by a process of attrition, disintegration and dissolution, which transforms it into a sandheap of individuals." The more "the inner and organic bond of the genuine and spontaneous community" gets lost, "the more it is held together by iron brackets of the modern bureaucratic and centralized State" (Röpke 1944, pp.239-240).

Furthermore, in Röpke's considerations, we can find the idea of balancing the logic of mass society by the intelligence of the individuals, when he wrote that "mass society [...] must be counteracted by individual leadership" (Röpke 1961, p.130). ${ }^{16}$ Röpke in no way meant a greater influence of experts who to the contrary too often are "intellectually insecure and little constant," but he considered essential a moral leadership that is aware of the "human constants" and that he called "clerks." In this way, the "revolt of the masses" should be opposed by "revolt of the elites" (Röpke 1944, p.223; 1961, pp.130). Röpke stressed much on this important insight that the free market as a condition of the society, which fulfils an integrating function without sacrificing its advantages in the creation of a free civil society, not only is realized by the idea of ordo but also needs an active moral elite. For Rosmini as well as Röpke, the degeneration of civil society in mass society is seen as a real threat. According to Rosmini this is specifically the modern form of "despotism" and a permanent danger for free societies. This can be dispelled only by the moral consciousness of the anthropological view on human being, which has

16 "Besides and above the State there must always be a layer of people who defend those pre- and supranational forces and values against the sonorous tyranny of society and against the coercive power of the State which tends to boundlessness: these brave, undeterred and independent people are a living embodiment of the sentence that, although one should render unto Caesar what is Caesar's, he must also render to God what is God's" (Röpke 1944, p.219). 
evolved from ancient times through Christianity in a long cultural history.

For Röpke, the market is a "consumer of morality” (Röpke 1950, pp.51-53; 1961, p.126). Therefore, it needs moral sources that lie beyond the market. In addition, in this aspect, we can find an essential agreement with the analysis of Rosmini, who could perfectly approve the following summary of Röpke: "The individual principle in the core of market economy must be balanced by the social and humanitarian principle. Both should exist in our modern society and at the same time ban the deadly dangers of massification and proletarianization" (Röpke 1944, p.83). For both thinkers, the market is embedded in a social context of moral freedom and therefore depends on pre-social moral resources beyond the market. Therefore, both are characterized by a consistent rejection of a planned economy and by the enhancement of the single individual in its natural and social relations. ${ }^{17}$ If Rosmini stressed that "the individual is nothing, where the government is everything" (Rosmini 1978, p.99), ${ }^{18}$ we found such remarks almost verbatim in the paper by Röpke (2006, p.61). As it emerges from the abovequoted study by Liermann (2004), Rosmini's idea of society is "civil, solidary, inclusive, open to development, performance-oriented and applied to compromise" (Liermann 2004, p.505). This seems to be like a precise echo of the values of liberalism according to Röpke: "humanist," "personalistic," "antiauthoritarian," "universalistic", and "rational."

\section{Conclusion}

Certainly, one of the obvious conclusions of this paper is that the topic Antonio Rosmini's Social Ethics and its relationship to German Thought presents not so much an account but rather a project - however, with good presuppositions. For the research on Rosmini, this paper means a new view on his economic and social-ethical thought itself. To the "German thought," this project contributed to the analysis of a new liberal

17 Rosmini introduced in this respect his doctrine of the "three societies" (Hoevel 2013, pp.211-232).

18 For Rosmini, "the great means, whose invention they [Fourier and the early socialists through to the young Marx] boast, in order to raise humanity out of renunciation and misery and redeem their glorious promise to make them permanently happy, ultimately consists in establishing a very rich and powerful government that is tasked to organize and collect all people in perfect way [...] this government would no longer be limited in its arrangements by the current socalled justice [...] because it need not to do concessions neither to religion nor to the recognition of property or of family bonds, nor to the individual rights" (Rosmini 1978, p.95, 108). catholic thinker who did not depend on the paradigm of social market economy, which has been elaborated in the German reflection. Therefore his approach includes also a number of incommensurable aspects. These aspects turn out to be extremely interesting, as some coordinates of the original theory concept have changed by the effects of globalization, late modernity, and post-secular society. Significantly, Rosmini's perspective contains innovative reasoning on how to answer these challenges: His social market economy idea is significantly less oriented on the government than the ordo-liberal thinking and embeds the economy in a "natural" social context. Furthermore, it is not based on the modern idea of individuality without relational embedding: such individuality in the late modern dynamic has bigger problems to position itself morally and to acquire the sense resources in a Röpkean understanding. Finally, Rosmini had a greater consideration of the religious element in the dynamics of the social-ethical integration of social systems and therefore he presented an idea of market economy, which is more sensitive to these elements. Rosmini stands for a much more sound idea of "person" and therefore precisely those elements that are claimed by Caritas in veritate to answer the actual trends. In this sense, a rereading of social market economy "with Rosmini" can open inspiring perspectives.

Such a "project," must begin with the compilation of the various texts of economic and social-ethical character, because Rosmini's reflections are spread across his entire work. Later, these would need to be translated into German. These texts can be classified through 16 topics which show again the similarity of his social-ethical thought with the idea of social market economy:

1. The humanistic power of Christianity

2. Against socialism

3. The "pre-social" reality of the person

4. Private property

5. Anti-despotism and anti-perfectionism

6. Competition as a society principle

7. Ordo, Constitution, and social justice

8. Common good

9. The task of the government

10. Tax and labor market policy

11. The problem of the welfare state

12. Happiness and satisfaction as goals of the society

13. Family and religion, "pre-social" realities of the person

14. Religion as guarantee against despotism

15. The principle of social development

16. The economy in the overall context of sciences 
Baggio A., Incivilimento e storia filosofica nel pensiero di Antonio Rosmini, Università di Trento. Dipartimento di lettere e filosofia, Trento, 2016.

Behr T.C., Luigi Taparelli D'Azeglio, SJ (1793-1862) and the development of scholastic natural law thought as a science of society and politics, J Markets Moral 6, 99-115, 2003.

Calza G., Perez P., Esposizione ragionata della filosofia di Antonio Rosmini. Con uno sguardo al luogo ch'ella tiene fra l'antica scienza e la nova, 2 Vols. Bertolotti, Intra, 1878-1879.

Campanini G., Antonio Rosminis politische Philosophie: Vom Staat zur società civile, In: Autiero A., Menke K.H. (Eds.), Brückenbauer zwischen Kirche und Gesellschaft - A. Rosmini, J. H. Newman, M. Blondel und R. Guardini, LIT, Münster, 135-148, 1999.

Cantillo G., Pietro Piovani, ein Interpret von Antonio Rosmini-Serbati - Zur Einführung in "Die gesellschaftliche Theodizee bei Rosmini”, In: Piovani P. (Ed.), Abhandlungen zur gesellschaftlichen Theodizee bei Antonio Rosmini-Serbati, 2 Vols. translated by M. W. Hebeisen (Ausgewählte Werke von Pietro Piovani in deutscher Übersetzung, I,3), Schweizerischer Wissenschafts- und Universitätsverlag, Biel, Bienne, 15-71, 2013.

D’Addio M., Sturzo e Rosmini, In: Universalità e cultura nel pensiero di Luigi Sturzo. Atti del Convegno Internazionale di studio (1999), Rubbettino, Soveria Mannelli, 63-102, 2001.

Eucken W., The Foundations of Economics. History and Theory in the Analysis of Economic Reality, translated by Hutchison T.W., Springer, Berlin et al., 1992.

Filangieri G., La scienza della legislazione, Grimaldi, Napoli, 2003.

Genovesi A., Lezioni di commercio o sia di economia civile, Società Tipografica dei Classici Italiani, Milano, 1824.

Ghia F., Marangon P., Rosmini e l'economia. Oltre lo stupore, Rosmini Stud, 2, 195-200, 2015.

Gioia M., Nuovo prospetto delle scienze economiche, 6 Vols., Ruggia, Lugano, 1838-1839.

Graziani A., Le idee economiche del Manzoni e del Rosmini (Rendiconti, Serie II, 20), Bernadori, Milano, 1887.

Hebeisen M.W., Vorwort des Übersetzers und Herausgebers, In: Piovani P. (Ed.), Abhandlungen zur gesellschaftlichen Theodizee bei Antonio Rosmini-Serbati, 2 Vols., translated by M. W.
Hebeisen (Ausgewählte Werke von Pietro Piovani in deutscher Übersetzung, I,3), Schweizerischer Wissenschafts- und Universitätsverlag, Biel, Bienne, 5-14, 2013.

Hegel G.W.F., Outlines of the Philosophy of Right, translated by Knox T.M., edited by Houlgate S., Oxford University Press, Oxford-New York, 2008.

Hoevel C., The economy of recognition. Person, Market and Society in Antonio Rosmini, Springer, Dordrecht, 2013.

Kobusch T., The discovery of the person. Metaphysics of freedom and modern image of man, Wissenschaftliche Buchgesellschaft, Darmstadt, 2nd edition, 1997.

Krienke M., Menschenwürde als notwendig anerkannte Freiheit in Hegel und Rosmini. Wie kann "intersubjektive Allgemeinheit" gedacht werden?, In: Fiorillo V., Kahlo M. (Eds.), Wege zur Menschenwürde. Ein deutsch-italienischer Dialog, Mentis, Münster, 223-248, 2015.

Küppers A., Soziale Gerechtigkeit im Verständnis der Katholischen Soziallehre, In: Rauscher A. (Ed.), Handbuch der Katholischen Soziallehre, Duncker \& Humblot, Berlin, 165-174, 2008.

Küppers A., Gerechtigkeit in der Marktwirtschaft, In: Rauscher A. (Ed.), Das Ringen um die Soziale Marktwirtschaft, Bachem, Köln, 85-103, 2010.

Lampertico F., Antonio Rosmini o delle relazioni fra il pensiero e la parola (Atti della R. Accademia della Crusca), Cellini, Firenze, 1897a.

Lampertico F., Antonio Rosmini o la sapienza e la scienza nella vita. Discorso pronunciato il 2 Maggio 1897 in Rovereto nella commemorazione del primo centenario dalla nascita di Antonio Rosmini, Cogliati, Milano, 1897b.

Liermann C., Rosminis politische Philosophie der zivilen Gesellschaft (Rechts- und Staatswissenschaftliche Veröffentlichungen der Görres-Gesellschaft), Schöningh, Paderborn et al, 2004.

Mbida Ngono J.P., La justice sociale: un concept catholique. Luigi Taparelli d'Azeglio et Antonio Rosmini Serbati, Téqui, Paris, 2017.

Minghetti M., Della economia pubblica e delle sue attinenze colla morale e col diritto, Succ. Le Monnier, Firenze, 2nd edition, 1868.

Muscolino S., Persona e mercato. I liberalismi di Rosmini e Hayek a confronto (La Rosminiana, 2), Rubbettino, Soveria Mannelli, 2010.

Nicoletti M., Ein "Hüter der Verfassung" im politischen Denken Italiens im 19. Jahrhundert: Antonio 
Rosmini und die Konzeption eines "politischen Gerichts”, In: Autiero A., Menke K.H. (Eds.), Brückenbauer zwischen Kirche und Gesellschaft - A. Rosmini, J. H. Newman, M. Blondel und R. Guardini, LIT, Münster, 149-166, 1999.

Piovani P., La teodicea sociale di Rosmini, CEDAM, Padova, 1957.

Piovani P., Abhandlungen zur gesellschaftlichen Theodizee bei Antonio Rosmini-Serbati, 2 Vols., translated by M. W. Hebeisen (Ausgewählte Werke von Pietro Piovani in deutscher Übersetzung, I,3), Schweizerischer Wissenschafts- und Universitätsverlag, Biel, Bienne, 2013.

Pisu G., II dibattito fra Marco Minghetti e Giuseppe Todde sulla Scienza economica, In: Gherardi R., Matteucci N. (Eds.), Marco Minghetti statista e pensatore politico. Dalla realtà italiana alla dimensione europea, II Mulino, Bologna, 269320, 1988.

Romagnosi G., Genesi del Diritto Penale, Stamp. del R. I. Monst. di S. Salvatore, Pavia, 1791.

Romagnosi G., Vedute fondamentali sull'arte logica, edited by L. Caboara (Opere scelte di Giandomenico Romagnosi, 1), Reale Accademia d'Italia, Roma, 1936.

Röpke W., Civitas humana. Grundfragen der Gesellschafts- und Wirtschaftsreform, Eugen Rentsch, Erlenbach-Zürich, 1944.

Röpke W., The social crisis of our time, translated by Schiffer Jacobsohn, A. and P., The University of Chicago Press, Chicago, 1950.

Röpke W., A humane economy. The social framework of the free market, translated by Henderson E., Henry Regnery, Chicago, 1961.

Röpke W., La necessità morale della libertà economica, In: Lottieri C. (Ed.), II Vangelo non è socialista. Scritti su etica cristiana e libertà economica (19591965), Rubbettino, Soveria Mannelli, 59-63, 2006.

Rosmini A., Della naturale costituzione della società civile, Paoli F. (Ed.), Grigoletti, Rovereto, 1887.

Rosmini A., Die fünf Wunden der Kirche, translated by Erbes P.J., Schöningh, Paderborn, 1971.

Rosmini A., II comunismo ed il socialismo, In: Rosmini A., Opuscoli politici, Marconi G. (Ed.) (Edizione critica, 37), Città Nuova, Roma, 81-121, 1978.

Rosmini A., Storia e critica comparativa de' sistemi intorno al principio della morale, In: Rosmini A., Principi della scienza morale, Muratore U. (Ed.) (Edizione critica, 23), Città Nuova, Roma, 161-459, 1990.

Rosmini A., Rights of the individual (The philosophy of right, 2), translated by Cleary D., Watson T., Rosmini House, Durham, 1993.
Rosmini A., The summary cause for the stability or downfall of human societies (The philosophy of politics, 1), translated by Cleary D., Watson T., Rosmini House, Durham, 1994a.

Rosmini A., Society and its purpose (The philosophy of politics, 2), translated by Cleary D., Watson T., Rosmini House, Durham, 1994b.

Rosmini A., Philosophie der Politik, translated by Liermann C., Tyrolia, Innsbruck, Wien, 1999.

Rosmini A., La Costituzione secondo la giustizia sociale, In: Rosmini A., Scritti politici, Muratore U. (Ed.), Sodialitas, 2nd edition, Stresa, 37-245, 2010.

Siep L., Was heißt: "Aufhebung der Moralität in Sittlichkeit” in Hegels Rechtsphilosophie?, Hegel-Studien, 17, 75-96, 1982.

Sturzo L., Politica e morale (1938). Coscienza e politica (1953) (Opere, 1), Zanichelli, Bologna, 1972.

Taparelli L., La Libertà in economia, La Civiltà Cattolica, 4, 33-53, 159-174, 414-433, 1860.

Taparelli L., Saggio teoretico di Diritto naturale appoggiato sul fatto, 2 Vols., La Civiltà Cattolica, 2nd edition, Roma, 1928.

Tarantino A., Natura delle cose e società civile. Rosmini e Romagnosi, Studium, Roma, 1983.

Toniolo G., Trattato di economia sociale e scritti economici, 5 Vols. (Opera omnia, II, 1-5), Comitato Opera omnia di G. Toniolo, Città del Vaticano, 1949-1952.

Toniolo G., Scolastica ed Umanesimo nelle dottrine economiche al tempo del Rinascimento in Toscana, In: Toniolo G., Dei Remoti fattori della Potenza economica di Firenze nel medio evo e scritti storici (Opera omnia, I), Comitato Opera omnia di G. Toniolo, Città del Vaticano, 291-371, 1952.

Traniello F., Revolution und Verfassung bei Antonio Rosmini, In: Autiero A., Menke K.H. (Eds.), Brückenbauer zwischen Kirche und Gesellschaft - A. Rosmini, J. H. Newman, M. Blondel und R. Guardini, LIT, Münster, 115-133, 1999.

Traniello F., Die Wundmale des Gekreuzigten als Paradigma für die Geschichte der Kirche, In: Krienke M. (Ed.), Rosmini und die deutsche Philosophie - Rosmini e la filosofia tedesca (Philosophische Schriften, 71), Duncker \& Humblot, Berlin, 403-414, 2007.

Veith W., Gerechtigkeit, In: Heimbach-Steins M. (Ed.), Christliche Sozialethik. Ein Lehrbuch, Vol. 1, Grundlagen, Pustet, Regensburg, 315-326, 2004.

Zoppi G.B., Antonio Rosmini e l'Economia politica, In: Per Antonio Rosmini nel primo centenario dalla sua nascita, 2 Vols., Cogliati, Milano, I, 407-450, 1897. 